\title{
32. CHEMICAL AND SR-ISOTOPIC COMPOSITION OF IGNEOUS ROCKS FROM DEEP SEA DRILLING PROJECT LEGS 59 AND 60
}

\author{
Richard Lee Armstrong and Graham T. Nixon, Department of Geological Sciences, \\ The University of British Columbia, Vancouver, B.C., Canada V6T 1W5
}

\begin{abstract}
The igneous rocks of Holes 447A, 448, 448A, 458, and 459B are ocean-ridge type basalt, arc tholeiite, tholeiitic basalt, magnesian andesite (similar to boninite), and basaltic andesite (that is transitional between tholeitic and calc-alkaline types), respectively. The magnesian andesites are notable for their low $\mathrm{Na}_{2} \mathrm{O}(\sim 1.7 \mathrm{wt} . \%)$ and $\mathrm{TiO}_{2}(0.25$ wt. $\%)$ and high $\mathrm{Mg} /\left(\mathrm{Mg}+\mathrm{Fe}^{2+}\right)(0.65$ and 0.64$)$ and for their degree of $\mathrm{SiO}_{2}$ enrichment $(51.11$ and 56.00 wt. $\%)$.

Compared to ocean-ridge basalts, arc and remnant-arc volcanic rocks are markedly enriched in $\mathrm{Rb}, \mathrm{Sr}$, and $\mathrm{Ba}$ and depleted in $\mathrm{Cr}$ and $\mathrm{Ni}$. V is variable - high in two remnant-arc (Site 448$)$ samples ( $\sim 400 \mathrm{ppm})$ and very low $(\sim 160 \mathrm{ppm})$ in the magnesian andesites. $\mathrm{Zr}$ shows only a slight decrease from ocean-ridge to arc rocks. The magnesian andesites are depleted in $\mathrm{Sr}, \mathrm{Zr}$, and $\mathrm{Y}$ and more enriched in $\mathrm{Cr}$ and $\mathrm{Ni}$ than other arc rocks. Highest $\mathrm{K} / \mathrm{Rb}$ ratios (790) occur in Site 448 remnant-arc samples. For all sites the immobile elements $\mathrm{Ti}, \mathrm{Y}, \mathrm{Zr}$, and $\mathrm{Nb}$ fall in the range characteristic of subalkaline basalts.

Initial ${ }^{87} \mathrm{Sr} /{ }^{86} \mathrm{Sr}$ isotopic ratios are low for the ridge-type basalts of Hole $447 \mathrm{~A}(0.70261)$, just as these ratios are for other MORB. Mariana Arc samples (Holes 458 and 459B) average 0.70381 and 0.70364 , distinctly more radiogenic than MORB, and thus are like other volcanic-arc samples from the circum-Pacific region. The remnant-arc samples (Holes 448 and $448 \mathrm{~A})$ are slightly less radiogenic $(0.70356$ and 0.70333$)$ than MORB. The ${ }^{87} \mathrm{Sr} /{ }^{86} \mathrm{Sr}$ ratio for samples from Holes 448 and $448 \mathrm{~A}$ appears to increase slightly as the rocks become younger and more differentiated.
\end{abstract}

\section{INTRODUCTION}

We were invited to participate in DSDP Legs 59 and 60 to provide precise $\mathrm{Sr}$-isotopic data for igneous rocks of this transect across an active volcanic arc-marginal base region. The obvious long-term goal was to characterize completely suites of samples from each tectonic element of the transect as to petrography, major- and trace-element chemistry, and isotope composition $(\mathrm{Sr}$, $\mathrm{Pb}, \mathrm{Nd}$, and $\mathrm{O}$ ). This information would then be the foundation for speculations concerning the origin of the diverse types of igneous rocks and the geochemical evolution of the crust and mantle. In this chapter our contribution toward the long-term goal is largely descriptive-the chemistry and $\mathrm{Sr}$-isotope composition of four suites of samples from the transect.

Our request to DSDP was for a limited number of the freshest rocks recovered on both Legs 59 and 60 . We were provided with three samples from each of four sites. In many holes fresh basement was not encountered, and several of the samples we analyzed, although presumably the freshest available, are quite altered-with unknown additions from, losses to, or exchange with circulating pore fluids.

The relative topographic and longitudinal position of our sample suites is illustrated in Figure 1. The westernmost hole (447A) is located on the east side of the West Philippine Basin at a depth of 6022 meters. Holes 448 and $448 \mathrm{~A}$ are on the west side of the Palau-Kyushu Ridge in a water depth of 3483 meters. Karig (1971; $1972 ; 1973$ ) interprets this feature as a remnant arc.

We did not receive samples from the Parece Vela Basin, West Mariana Ridge, or Mariana Trough so that

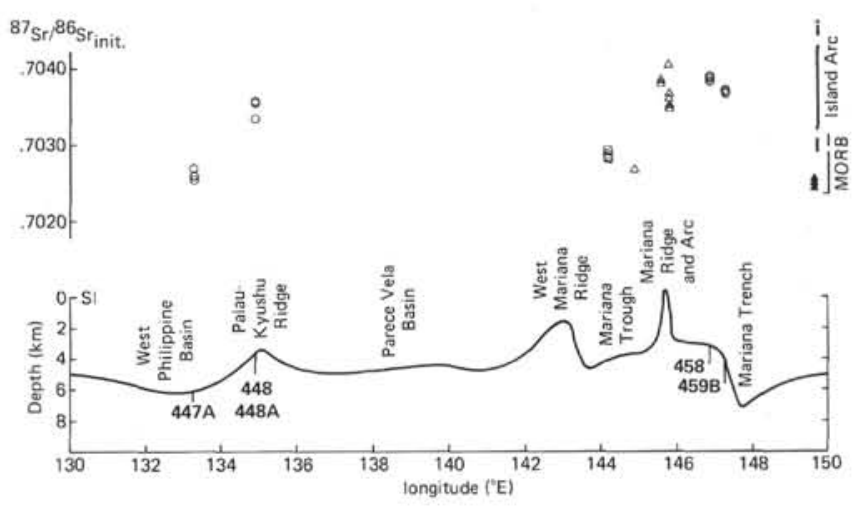

Figure 1. Sr-isotopic composition and topographic profile of Legs 59 and 60 transect across the Mariana Arc and West Philippine Basin. Open circles = our new data for Legs 59 and 60 samples; open squares = data from Hart et al. [1972]; open triangles = data from Meijer [1976]; closed triangles on the right-hand edge of the profile $=$ our samples from the Juan de Fuca Ridge.)

our hopes of a complete isotopic profile across the arc-remnant arc system were not realized. Part of this gap is filled by published $\mathrm{Sr}$-isotopic data for the Mariana Trough (Hart et al., 1972). Meijer (1976) reported isotopic data for islands in the Mariana Arc itself, and for one sample from the Mariana Trough. Stern (1979) presented four analyses for arc rocks about $2^{\circ}$ north of the DSDP transect.

Our two easternmost holes (458 and 459B), in water depths of 3447 and 4121 meters, respectively, are in the Mariana Arc-Trench gap just west of the trench-slope break. The rocks at these two sites are subaqueously erupted arc volcanics, not accreted ocean floor (Meijer, 1978; Hussong, 1978). 


\section{SAMPLE DESCRIPTIONS}

\section{Leg 59}

At Hole 447A, 113.5 meters of sediment and 183 meters of basalt flows were penetrated. The three samples supplied to us come from depths of 143.5, 170.1, and 191.5 meters below the seafloor and are assigned to Units $8 \mathrm{a}, 8 \mathrm{c}$, and 10 in the Site 447 report, this volume. All three are relatively fresh.

Sample $447 \mathrm{~A}-17-3,49-53$ and $58-61 \mathrm{~cm}$ is fresh basalt from pillow basalts with fresh glassy rims and phenocrysts of plagioclase, augite, and olivine. The two rock chips analyzed contain calcic andesine and clinopyroxene phenocrysts in a dark glassy groundmass partially altered to orange-brown clay and containing clayfilled vesicles.

Sample 447A-21-2, 114-119 cm is from the same lithologic unit as the previous sample. Phenocrysts and glomerocrysts of calcic andesine occur in a groundmass of plagioclase microlites, granular clinopyroxene, and $<5 \%$ glass altered to orange-brown clay minerals.

Sample 447A-25-1, 49-54 cm is from the lower interior part of a thick flow with clinopyroxene and andesine to labradorite microphenocrysts in a mediumgrained subophitic holocrystalline groundmass. It is quite fresh.

At Holes 448 and 448A, 337.5 meters of sediment and 576.5 meters of igneous and fragmental igneous rocks were penetrated. The three samples with which we were supplied come from depths of 549.3, 664, and 727 meters below the seafloor and represent Units 13, 20, and 26 , respecively. All are moderately altered.

Sample 448-61-3, 26-32 cm is from a basalt flow near the bottom of Hole 448. Andesine and clinopyroxene phenocrysts occur in an intergranular groundmass composed of plagioclase, clinopyroxene, and $\sim 10 \%$ to $15 \%$ dark orange-brown glass altered to clay.

Sample 448A-33-1, $100-108 \mathrm{~cm}$ is from altered aphyric basalt containing veins and granules of copper and green smectite (Site 448 report, this volume). Microphenocrysts of calcic andesine, clinopyroxene, and opaque oxide (titanomagnetite) occur in an intergranular, oxide-rich, altered glassy groundmass. Empty vesicles make up about $5 \%$ of the rock.

Sample $448 \mathrm{~A}-41-1,2-7 \mathrm{~cm}$ is from a dike or sill or steeply dipping flow of plagioclase-phyric basalt. Calcic-andesine phenocrysts and glomerocrysts occur in a hyalo-ophitic and vesicular groundmass with andesine laths, clinopyroxene, abundant opaque oxide, and glass altered to clay.

\section{Leg 60}

At Hole 458, 256.5 meters of sediment and 209 meters of igneous rock were penetrated. Two of our samples come from depths of 279 and 310 meters below the seafloor in the part of the section containing peculiar, glassy, two-pyroxene basaltic rocks called boninites in the initial descriptions (Units 1 and 2) (Saunders et al., 1978; Meijer, 1978). The third sample comes from a depth of 438 meters in a section containing Unit 5 fractured basalts. The samples are moderately to highly altered.

Sample 458-30-2, $51-53 \mathrm{~cm}$ is from pillow basalts with irregular patches and streaks of small vesicles. Relict plagioclase and pyroxene occur in a cloudy, hydrated, and oxidized amygdaloidal groundmass.

Sample 458-33-2, 74-77 cm is from fractured and altered vesicular basalt. Andesine to labradorite, abundant augite, and opaque oxide occur in hyalo-ophitic texture in glass altered to dark brown clay. Vesicles contain green and brown clay minerals. Plagioclase is partially altered.

Sample $458-47-1,131-134 \mathrm{~cm}$ is dark altered vesicular metabasalt from massive pillow lavas. Plagioclase and a few opaque oxide grains occur in an altered glassy groundmass-now yellowish brown clay. Brown clay minerals also fill vesicles.

At Hole 459B, 559 meters of sediment and 132.5 meters of basalt were penetrated. Our samples come from depths of 572, 617, and 644.5 meters below the seafloor and represent Units 1, 3, and 4, respectively. All three samples are moderately altered.

Sample 459B-61-2, $42-46 \mathrm{~cm}$ is from a thick flow or sill. Andesine to labradorite microlites and clinopyroxene grains occur in hyalo-ophitic texture in a dark brown glassy groundmass impregnated with opaque oxides. Vesicles are lined with green to yellow-brown clay. Scattered patches of calcite are present.

Sample 459B-66-1, 100-102 cm is from a coarse, vesicular, aphyric diabase sill. Partially altered calcic andesine, clinopyroxene, and magnetite occur in hyaloophitic texture in altered glass composed of clay and celadonite. Interstitial quartz and alkali feldspar are present.

Sample 459B-69-1, $47-50 \mathrm{~cm}$ is from vesicular pillow basalts. Plagioclase phenocrysts and laths and rare clinopyroxene grains occur in an altered fine-grained groundmass. Brown to green clay minerals line vesicles.

\section{Comparison Suite}

R. L. Chase (University of British Columbia) provided three dredge samples of basalt from the Juan de Fuca (JdF) Ridge, which represent fresh northwest Pacific ocean floor and are fairly typical of mid-ocean ridge basalt (MORB) in general.

JdF-P-269-6-4 $\left(49^{\circ} 03^{\prime} \mathrm{N}, 130^{\circ} 54^{\prime} \mathrm{W}\right)$ is from the east flank of the Explorer Seamount at a depth of 1600 meters. The sample is spherulitic glass from the margin of a pillow with several per cent olivine phenocrysts.

JdF-70-025-2D-8 $\left(50^{\circ} 53.7^{\prime} \mathrm{N}, 130^{\circ} 36.6^{\prime} \mathrm{W}\right)$ is from the northwest Dellwood Knoll at a depth of 1800 meters (Bertrand, 1972). The sample is composed of fragments of vesicular basalt with scattered olivine phenocrysts.

JdF-71-23-3 $\left(48^{\circ} 31^{\prime} \mathrm{N}, 128^{\circ} 55^{\prime} \mathrm{W}\right)$ is from “West Ridge"' at the north end of the Juan de Fuca Ridge at a depth of 2500 meters (Barr, 1972). The sample is a pillow fragment comprising glassy rim plus fine-grained interior, with about $10 \%$ olivine phenocrysts 0.5 to 2 $\mathrm{mm}$ across. 


\section{CHEMISTRY}

Analyses and CIPW norms are presented in Table 1, arranged geographically from west to east and in order of increasing depth in each hole. Analytic techniques and precision are reported in the Appendix. Atomic $\mathrm{Mg} /\left(\mathrm{Mg}+\mathrm{Fe}^{+2}\right)$ values have been calculated after adjustment to a fixed oxidation state of iron such that $\mathrm{Fe}_{2} \mathrm{O}_{3} /$ (total iron as $\left.\mathrm{FeO}\right)=0.1$. The convention for oxidation in the CIPW norms was taken from the relationship $\mathrm{Fe}_{2} \mathrm{O}_{3}=\mathrm{TiO}_{2}+1.5$ (Irvine and Baragar, 1971).

\section{Alteration}

The effects of submarine weathering on ocean-floor basalts have been extensively documented (for example, Hart, 1969; 1971; Hart and Nalwalk, 1970; Hart et al., 1974) and various alteration parameters used to discriminate between fresh and altered oceanic basalts. Selected alteration parameters presented in Figure 2 show withinand between-site variation. On the basis of $\mathrm{H}_{2} \mathrm{O}^{+}$contents (Hart and Nalwalk, 1970; Hart et al., 1974), the freshest samples are from the West Philippine Basin (Hole 447A) and Juan de Fuca Ridge. Arc and remnantarc samples are moderately to extensively altered, with $\mathrm{H}_{2} \mathrm{O}^{+}$in the range 0.55 to 1.38 wt. $\%$. All samples except one from Hole 458 and one from Hole 459B have greater than $0.3 \mathrm{wt} . \% \mathrm{CO}_{2}$, and oxidation ratios are generally high $\left(\mathrm{Fe}^{+3} /\left[\mathrm{Fe}^{+3}+\mathrm{Fe}^{+2}\right] \geq 0.4\right)$. Large amounts of absorbed water in samples from Hole 458 may have accompanied modification of other components. For example, 5.11 wt. $\% \mathrm{H}_{2} \mathrm{O}^{-}$occurs in a magnesian andesite (Sample 458-30-2, 51-53 cm) whose chemistry suggests leaching of silica with possible addition of $\mathrm{K}_{2} \mathrm{O}$ when compared to a petrographically identical sample (458-33-2, 74-77 cm). In general, however, no overall correlation exists between alteration parameters and the major oxides. Abundances and ratios of alkali elements, most likely to have been substantially changed by alteration processes, appear normal. $\mathrm{Mg}$ / $\left(\mathrm{Mg}+\mathrm{Fe}^{+2}\right)$ values in samples from the Palau-Kyushu Ridge and Mariana fore-arc region exhibit a strong negative correlation with total iron as $\mathrm{FeO}$ and appear to be a reliable index of differentiation. Uniform ${ }^{87} \mathrm{Sr} /{ }^{86} \mathrm{Sr}$ within each site suggests that alteration has not greatly modified $\mathrm{Sr}$-isotopic ratios or $\mathrm{Sr}$ concentrations. Trace elements generally considered "immobile," for example, Y, Zr, and $\mathrm{Nb}$ (Cann, 1970; Pearce and Cann, 1973), are probably also intact.

\section{Major Elements}

All samples studied are typical mid-ocean ridge basalts or island-arc tholeiites transitional to calc-alkaline compositions. Intra- and intersite variations of selected major-element oxides and average trends are shown in Figure 3. Arc and remnant-arc basalts and basaltic andesites are distinguished from ocean-floor tholeiites of the West Philippine Basin by higher overall $\mathrm{SiO}_{2}$ and $\mathrm{K}_{2} \mathrm{O}$ and lower $\mathrm{CaO}, \mathrm{TiO}_{2}$ and $\mathrm{Mg} / \mathrm{Mg}+$ $\mathrm{Fe}^{+2}$ ). As a general guide to their chemical affinities, all island-arc rocks have been plotted in $\mathrm{SiO}_{2}$ and $\mathrm{FeO}^{t}$ ver- sus $\mathrm{FeO}^{t} / \mathrm{MgO}$ variation diagrams (Fig. 4, after Miyashiro, 1974; 1975).

Basalts of the Juan de Fuca comparison suite exhibit the general characteristics of MORB-low total alkalis, low $\mathrm{K}_{2} \mathrm{O}$ and $\mathrm{SiO}_{2}$, and high $\mathrm{CaO}$ and $\mathrm{MgO}$ (Melson et al., 1976). The high alumina of JdF-70-025-2D-8 causes it to fall just within the field of calc-alkaline rocks on a cation normative-plagioclase versus $\mathrm{Al}_{2} \mathrm{O}_{3}$ diagram (Irvine and Baragar, 1971). All three basalts are relatively undifferentiated with respect to $\mathrm{Mg} /\left(\mathrm{Mg}+\mathrm{Fe}^{+2}\right)$ (0.68-0.75), the most primitive being JdF-71-23-3, which approaches a picritic composition with extremely low $\mathrm{K}_{2} \mathrm{O}$ and high concentrations of compatible trace elements.

Ocean-floor basalts from Hole 447A in the West Philippine Basin are similar in composition to the Juan de Fuca suite and to MORB in general. Sample 447A-25-1, 49-54 cm, stratigraphically the lowest, is distinctly higher than the others in $\mathrm{MgO}$ and $\mathrm{Mg} /(\mathrm{Mg}+$ $\left.\mathrm{Fe}^{+2}\right)(0.72)$ and relatively depleted in $\mathrm{K}_{2} \mathrm{O}(0.04 \mathrm{wt} . \%)$. The two samples higher in the section have greater abundances of $\mathrm{K}_{2} \mathrm{O}(0.40-0.46 \mathrm{wt} . \%)$ and a greater degree of iron enrichment. Their $\mathrm{Mg} /\left(\mathrm{Mg}+\mathrm{Fe}^{+2}\right)$ values are too low for the lavas to be primary mantlederived melts.

The arc rocks analyzed in this study are chemically diverse. Remnant-arc basalts at Holes 448 and $448 \mathrm{~A}$ on the Palau-Kyushu Ridge show marked iron enrichment $\left(\mathrm{FeO}^{\mathrm{t}}=10.85-12.72\right.$ wt. \%), moderate $\mathrm{CaO}$ abundances (8.55-9.24 wt. \%), and very low $\mathrm{Mg} /(\mathrm{Mg}+$ $\left.\mathrm{Fe}^{+2}\right)(0.41-0.47)$. In the classification scheme of Miyashiro (1974) these rocks fall well within the field of island-arc tholeiites (Figure 4). Relatively low $\mathrm{Na}_{2} \mathrm{O}$ / $\mathrm{K}_{2} \mathrm{O}$ and normal to very high $\mathrm{K}_{2} \mathrm{O}$ concentrations $(0.30$ $1.16 \mathrm{wt} . \%$ ) distinguish these rocks from other arc tholeiites with similar silica contents (e.g., Jakeš and Gill, 1970). The high alumina of Samples 448-61-3, 26-32 cm and $448 \mathrm{~A}-41-1,2-7 \mathrm{~cm}$ may be partially a result of crystal accumulation in these plagioclase-phyric samples.

Samples from Hole 458 in the active arc-trench gap may be divided into two categories distinct in mineralogy and chemical composition: a tholeitic metabasalt (Sample 458-47-1, 131-134 cm) with plagioclase and clinopyroxene phenocrysts at the base of the section; and magnesian andesites with affinity to boninite.

Sample $458-47-1,131-134 \mathrm{~cm}$, is a high-alumina basalt showing moderate iron enrichment $(\mathrm{Mg} /[\mathrm{Mg}+$ $\left.\mathrm{Fe}^{+2}\right]=0.46$ ) that falls well within the tholeiitic fields of Figure 4. Although this rock is obviously altered, with high volatile content and high $\mathrm{Fe}^{+3} /\left(\mathrm{Fe}^{+3}+\mathrm{Fe}^{+2}\right)$ value, the chemical differences between it and overlying magnesian andesites cannot be explained by alteration alone.

The upper stratigraphic units in this hole are characterized by low $\mathrm{Na}_{2} \mathrm{O}(\sim 1.7 \mathrm{wt} . \%)$, extremely low $\mathrm{TiO}_{2}(\sim 0.25$ wt. $\%)$, and relatively high $\mathrm{K}_{2} \mathrm{O}(0.78-1.16$ wt. \%). Both samples lie within the calc-alkaline fields in Miyashiro's diagrams (Fig. 4). The least altered sample is most extreme in having a high value for $\mathrm{Mg} /(\mathrm{Mg}$ $\left.+\mathrm{Fe}^{+2}\right)(0.64)$ relative to the degree of silica enrich- 
Table 1. Volcanic rocks from DSDP Legs 59 and 60 and the Juan de Fuca Ridge: Chemical analyses, Sr-isotopic composition, and CIPW norms.

\begin{tabular}{|c|c|c|c|c|c|c|c|c|c|c|c|c|c|c|c|}
\hline $\begin{array}{c}\text { Sample } \\
\text { (interval in } \mathrm{cm} \text { ) }\end{array}$ & $\begin{array}{l}\text { 447A-17-3, } \\
49-53 \text { and } \\
58-61\end{array}$ & $\begin{array}{c}447 \mathrm{~A}-21-2 \\
114-119\end{array}$ & $\begin{array}{c}\text { 447A-25-1, } \\
\text { 49-54 }\end{array}$ & $\begin{array}{l}448-61-3 \\
26-32\end{array}$ & $\begin{array}{c}448 \mathrm{~A}-33-1 \\
100-108\end{array}$ & $\begin{array}{c}448 \mathrm{~A}-41-1, \\
2-7\end{array}$ & $\begin{array}{l}458-30-2, \\
51-53\end{array}$ & $\begin{array}{l}\text { 458-33-2, } \\
74-77\end{array}$ & $\begin{array}{l}458-47-1, \\
131-134\end{array}$ & $\begin{array}{c}459 \mathrm{~B}-61-2 \\
42-46\end{array}$ & $\begin{array}{c}459 \mathrm{~B}-66-1 \\
100-102\end{array}$ & $\begin{array}{c}459 \mathrm{~B}-69-1, \\
47-50\end{array}$ & JdF-70-025-2D-8 & JdF-P-269-6-4 & PdF-71-23-3 \\
\hline $\mathrm{SiO}_{2}$ & 50.62 & 49.93 & 48.56 & 50.14 & 52.50 & 50.03 & 51.11 & 56.00 & 51.85 & 52.39 & 57.16 & 56.97 & 47.87 & 47.00 & 49.20 \\
\hline $\mathrm{TiO}_{2}$ & 1.22 & 1.00 & 0.79 & 0.91 & 1.14 & 1.00 & 0.28 & 0.23 & 0.91 & 0.59 & 0.80 & 0.61 & 1.19 & 1.01 & 0.89 \\
\hline $\mathrm{Al}_{2} \mathrm{O}_{3}$ & 15.17 & 15.66 & 16.68 & 17.15 & 14.75 & 16.80 & 14.93 & 14.48 & 16.92 & 15.09 & 14.90 & 16.42 & 17.38 & 16.00 & 15.44 \\
\hline $\mathrm{Fe}_{2} \mathrm{O}_{3}$ & 4.06 & 4.68 & 2.15 & 5.45 & 5.89 & 6.62 & 5.84 & 3.26 & 6.99 & 3.82 & 6.32 & 3.72 & 4.17 & 1.84 & 0.93 \\
\hline $\mathrm{FeO}$ & 5.94 & 5.21 & 5.86 & 5.52 & 7.03 & 4.48 & 2.14 & 4.09 & 3.20 & 5.26 & 3.25 & 3.46 & 4.53 & 8.56 & 7.22 \\
\hline $\mathrm{MnO}$ & 0.17 & 0.16 & 0.14 & 0.14 & 0.18 & 0.16 & 0.09 & 0.11 & 0.09 & 0.14 & 0.12 & 0.09 & 0.16 & 0.18 & 0.15 \\
\hline $\mathrm{MgO}$ & 6.94 & 6.74 & 10.12 & 3.97 & 4.33 & 4.61 & 6.98 & 6.25 & 4.04 & 6.08 & 3.34 & 3.23 & 8.76 & 12.42 & 11.99 \\
\hline $\mathrm{CaO}$ & 11.33 & 12.22 & 11.56 & 9.24 & 8.62 & 8.55 & 8.54 & 10.83 & 6.65 & 11.29 & 7.30 & 8.65 & 11.89 & 10.64 & 11.23 \\
\hline $\mathrm{Na}_{2} \mathrm{O}$ & 2.21 & 1.98 & 2.21 & 2.15 & 1.89 & 1.60 & 1.72 & 1.69 & 2.10 & 2.34 & 2.80 & 2.65 & 2.39 & 2.11 & 1.96 \\
\hline $\mathrm{K}_{2} \mathrm{O}$ & 0.46 & 0.40 & 0.04 & 1.16 & 0.30 & 1.15 & 1.16 & 0.78 & 0.43 & 0.35 & 0.84 & 0.73 & 0.14 & 0.09 & 0.01 \\
\hline $\mathrm{P}_{2} \mathrm{O}_{5}$ & 0.15 & 0.13 & 0.10 & 0.13 & 0.12 & 0.11 & 0.05 & 0.06 & 0.10 & 0.11 & 0.11 & 0.10 & 0.13 & 0.11 & 0.09 \\
\hline $\mathrm{H}_{2} \mathrm{O}^{(+)}$ & 0.65 & 1.20 & 1.31 & 0.96 & 0.55 & 1.35 & 1.17 & 0.93 & 1.13 & 0.99 & 1.38 & 0.80 & 0.21 & 0.41 & 0.31 \\
\hline $\mathrm{H}_{2} \mathrm{O}^{(-)}$ & 1.04 & 1.08 & 0.59 & 2.10 & 2.42 & 2.90 & 5.11 & $\begin{array}{l}.93 \\
1.59\end{array}$ & 5.41 & 0.86 & 1.82 & 1.87 & 0.50 & 0.32 & 0.16 \\
\hline $\mathrm{CO}_{2}$ & 0.00 & 0.14 & 0.24 & 0.15 & 0.18 & 0.19 & 0.71 & 0.33 & 0.38 & 0.62 & 0.14 & 0.63 & 0.29 & 0.11 & 0.24 \\
\hline Total & 99.96 & 100.53 & 100.35 & 99.17 & 99.60 & 99.55 & 99.83 & 100.73 & 100.20 & 99.93 & 100.28 & 99.93 & 99.61 & 100.80 & 100.32 \\
\hline $\mathrm{FeO}^{\mathrm{ta}^{\mathrm{a}}}$ & 9.77 & 9.59 & 7.92 & 10.85 & 12.72 & 10.96 & 7.91 & 7.16 & 10.13 & 8.86 & 9.21 & & 8.38 & 10.20 & 8.11 \\
\hline $\mathrm{Mg} /\left(\mathrm{Mg}+\mathrm{Fe}+2^{\mathrm{b}}\right)$ & 0.59 & 0.59 & 0.72 & 0.43 & 0.41 & 0.47 & 0.65 & 0.64 & 0.46 & 0.58 & 0.43 & 0.48 & $\begin{array}{l}.3 .30 \\
0.68\end{array}$ & 0.71 & 0.75 \\
\hline $\mathrm{Fe}+3 /\left(\mathrm{Fe}+2+\mathrm{Fe}^{2}+3\right)$ & 0.43 & 0.50 & 0.59 & 0.52 & 0.48 & 0.62 & 0.75 & 0.47 & 0.71 & 0.45 & 0.68 & 0.54 & 0.51 & 0.19 & 0.12 \\
\hline $\mathrm{Cr}$ & 176 & 244 & 343 & 38 & 8 & 69 & 165 & 242 & 29 & 164 & 84 & 64 & 277 & 412 & 706 \\
\hline $\mathrm{v}$ & 312 & 287 & 198 & 330 & 407 & 409 & 142 & 172 & 367 & 271 & 296 & 232 & 209 & 198 & 199 \\
\hline $\mathrm{Ni}$ & 94 & 84 & 233 & 21 & 10 & 16 & 64 & 97 & 29 & 49 & 21 & 24 & 178 & 365 & 357 \\
\hline$R b$ & 9 & 6 & 0.8 & 13 & 4 & 14 & 13 & 16 & 8 & 14 & 22 & 23 & 2 & 2.5 & 0.1 \\
\hline Sr & 83 & 71 & 106 & 168 & 143 & 146 & 87 & 91 & 135 & 111 & 103 & 132 & 183 & 130 & 68 \\
\hline $\mathrm{Ba}$ & 9 & 8 & $<8$ & 71 & 44 & 45 & 23 & 34 & & & & & & & \\
\hline $\mathrm{Zr}$ & 83 & 70 & 68 & 84 & 61 & 51 & 46 & 44 & 29 & 28 & 40 & 36 & 14 & 10 & $<8$ \\
\hline $\mathrm{Nb}$ & $<3$ & 3 & $<3$ & $<3$ & $<3$ & 3 & $<3$ & 5 & 71 & 52 & 75 & 66 & 100 & 81 & 60 \\
\hline $\mathrm{Y}$ & 32 & 27 & 21 & 26 & 24 & 19 & 4 & 8 & 3 & 5 & 4 & $<3$ & 6 & 4 & $<3$ \\
\hline $\mathrm{Rb} / \mathrm{Sr}$ & 0108 & 0085 & 0.008 & 0.077 & & & & & 21 & 15 & 21 & 15 & 26 & 25 & 22 \\
\hline $87 \mathrm{Sr} / 86 \mathrm{Sr}$ obs. & $\begin{array}{l}0.108 \\
0.70269\end{array}$ & $\begin{array}{l}0.083 \\
0.70270\end{array}$ & $\begin{array}{l}0.008 \\
0.70270\end{array}$ & $\begin{array}{l}0.077 \\
0.70367\end{array}$ & $\begin{array}{l}0.025 \\
0.70360\end{array}$ & $\begin{array}{l}0.096 \\
0.70345\end{array}$ & $\begin{array}{l}0.149 \\
0.70402\end{array}$ & $\begin{array}{l}0.176 \\
0.70404\end{array}$ & $\begin{array}{l}0.059 \\
0.70392\end{array}$ & $\begin{array}{l}0.126 \\
0.70390\end{array}$ & $\begin{array}{l}0.214 \\
0.70406\end{array}$ & $\begin{array}{l}0.174 \\
0.70392\end{array}$ & $\begin{array}{l}0.011 \\
0.70240\end{array}$ & $\begin{array}{l}0.019 \\
0.70250\end{array}$ & 0.0015 \\
\hline${ }^{87} \mathrm{Sr} / 86 \mathrm{Sr}$ init. & 0.70254 & 0.70259 & 0.70269 & 0.70356 & 0.70356 & 0.70333 & 0.70381 & 0.70379 & 0.70384 & 0.70366 & 0.70367 & 0.70360 & 0.70240 & 0.70250 & $\begin{array}{l}0.70240 \\
0.70246\end{array}$ \\
\hline \multicolumn{16}{|l|}{ CIPW Norms } \\
\hline$q \mathrm{qz}$ & 3.10 & 2.60 & 0.00 & 5.30 & 12.19 & 8.23 & 8.20 & 12.74 & 15.34 & 6.43 & 15.77 & 16.59 & 0.00 & 0.00 & 0.00 \\
\hline or & 2.74 & 2.40 & 0.21 & 7.15 & 1.86 & 7.15 & 7.37 & 4.73 & 2.76 & 2.14 & 5.15 & 4.42 & 0.85 & 0.54 & 0.07 \\
\hline$a b$ & 19.07 & 17.18 & 19.03 & 18.87 & 16.55 & 14.19 & 15.63 & 14.69 & 19.14 & 20.18 & 24.55 & 23.09 & 20.42 & 17.96 & 16.64 \\
\hline an & 30.70 & 33.28 & 36.02 & 35.28 & 31.98 & 37.24 & 31.77 & 30.16 & 32.10 & 30.30 & 26.48 & 31.69 & 36.77 & 33.83 & 33.54 \\
\hline $\mathrm{di}$ & 20.79 & 21.78 & 16.05 & 8.93 & 8.63 & 4.56 & 6.93 & 17.98 & 0.00 & 18.10 & 7.77 & 6.35 & 16.20 & 14.08 & 16.43 \\
\hline hy & 16.90 & 16.54 & 16.15 & 18.44 & $\begin{array}{r}21.06 \\
\end{array}$ & 22.20 & 25.05 & 15.82 & 21.87 & $\begin{array}{l}10.94 \\
16.94\end{array}$ & 14.75 & 11.85 & 11.50 & $\begin{array}{r}11.00 \\
6.51\end{array}$ & $\begin{array}{l}19.43 \\
19.13\end{array}$ \\
\hline ol & 0.00 & 0.00 & 7.06 & 0.00 & 0.00 & 0.00 & 0.00 & 0.00 & 0.00 & 0.00 & 0.00 & 0.00 & 7.05 & $\begin{array}{r}0.31 \\
21.98\end{array}$ & $\begin{array}{l}10.17 \\
10.37\end{array}$ \\
\hline $\mathrm{mt}$ & 3.98 & 3.65 & $\begin{array}{l}7.00 \\
3.16\end{array}$ & 3.55 & $\begin{array}{l}0.00 \\
3.88\end{array}$ & 3.70 & 2.61 & 2.52 & 3.58 & $\begin{array}{l}0.00 \\
3.05\end{array}$ & $\begin{array}{l}0.00 \\
3.37\end{array}$ & $\begin{array}{l}3.00 \\
3.09\end{array}$ & $\begin{array}{l}3.05 \\
3.92\end{array}$ & $\begin{array}{r}2.98 \\
2.66\end{array}$ & $\begin{array}{l}1.37 \\
1.35\end{array}$ \\
\hline il & 2.37 & 1.93 & 1.52 & 1.81 & 2.24 & 2.01 & 0.58 & 0.46 & 1.85 & 1.15 & 1.58 & 1.20 & 2.29 & 1.92 & 1.71 \\
\hline ap & 0.35 & 0.32 & 0.23 & 0.31 & 0.29 & 0.26 & 0.13 & 0.14 & 0.26 & 0.26 & 0.25 & 0.24 & 0.31 & 0.27 & 0.20 \\
\hline $\mathrm{cc}$ & 0.00 & 0.33 & 0.56 & 0.36 & 0.43 & 0.46 & 1.74 & 0.77 & 0.93 & 1.45 & 0.33 & 1.48 & 0.67 & 0.25 & 0.55 \\
\hline
\end{tabular}

a ${ }^{\mathrm{FeO}} \mathrm{t}=$ total iron expressed as $\mathrm{FeO}$.
$\left.\mathrm{b}_{\mathrm{Mg} /(\mathrm{Mg}}+\mathrm{Fe}+2\right)=$ atomic ratio with $\mathrm{Fe}^{+2}$ standardized to $\mathrm{Fe}_{2} \mathrm{O}_{3} / \mathrm{FeO}^{\mathrm{t}}=0.1$ 


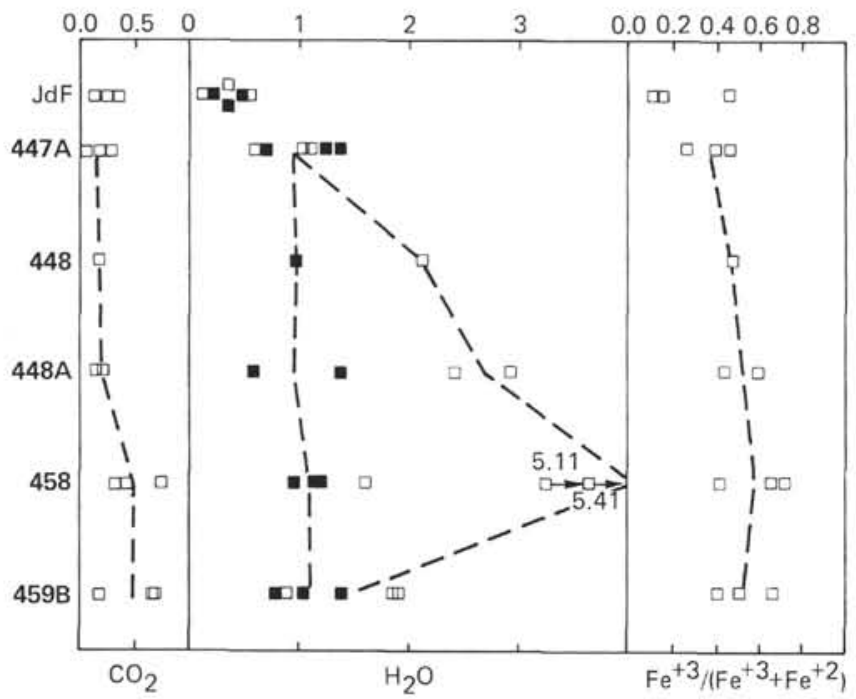

Figure 2. Variation of alteration parameters (wt. \%) at each sample locality. (Dashed lines indicate average trends. $\mathrm{H}_{2} \mathrm{O}^{+}$is shown as closed squares, $\mathrm{H}_{2} \mathrm{O}^{-}$as open squares.) ment (56 wt. \%; $12.74 \%$ normative quartz). It is interesting to note that rocks with similar characteristics but more extreme $\mathrm{Al}_{2} \mathrm{O}_{3}$ and $\mathrm{CaO}$ depletion and much higher $\mathrm{MgO}$ have been called boninites, and this term was used to describe some samples from Hole 458. In this paper we refer to Samples 458-30-2, $51-53 \mathrm{~cm}$ and 458-33-2, 74-77 $\mathrm{cm}$ as magnesian andesite (Kay, 1978). True boninites (Kikuchi, 1889) have been recognized in other fore-arc regions, notably in the inner wall of the Mariana Trench south of Guam (Hawkins et al., 1979), in the Bonin Islands (Kuroda et al., 1978), and in several ophiolite complexes (Cameron et al., 1979). Speculations by shipboard scientists concerning the origin of boninites (preliminary Site Report for DSDP Leg 60) involve partial melting of hydrous peridotite at fairly shallow mantle depths $(<10 \mathrm{~kb})$ at an early stage of island-arc develoment.

In contrast to the magnesian andesites of Hole 458, basaltic andesites at Hole 459B immediately to the east are some of the most evolved rocks in the suite. Samples 459B-66-1, 100-102 $\mathrm{cm}$ and 459B-69-1, 47-50 $\mathrm{cm}$ have $\mathrm{SiO}_{2}$ contents of approximately 57 wt. \%, moderate alumina (14.90 and $16.42 \mathrm{wt} . \%$, respectively), and low
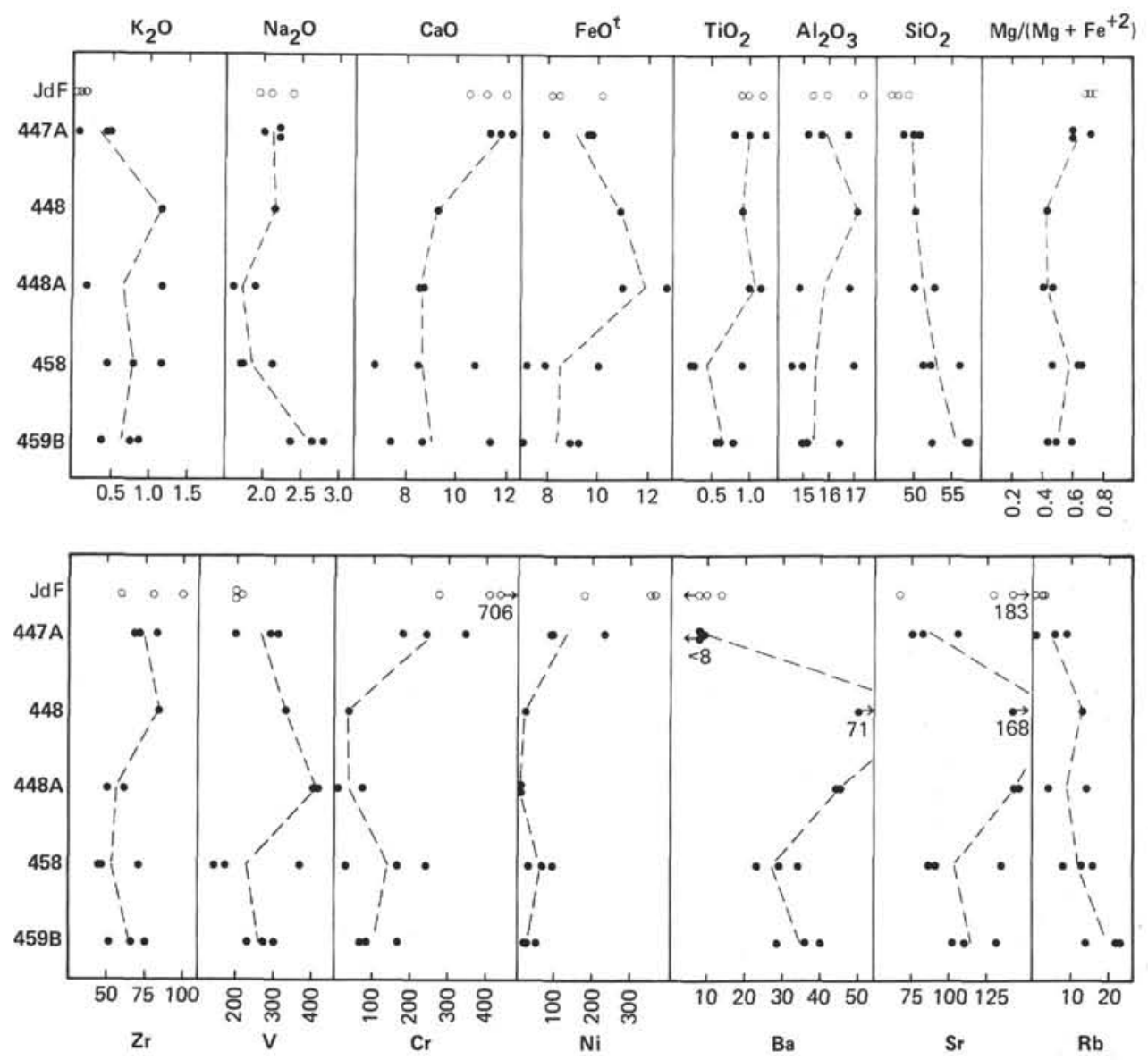

Figure 3. Selected major- and trace-element variations (wt. \% and ppm, respectively) within and between sites sampled in this study. (Open circles represent Juan de Fuca basalts; dashed lines show average trends.) 


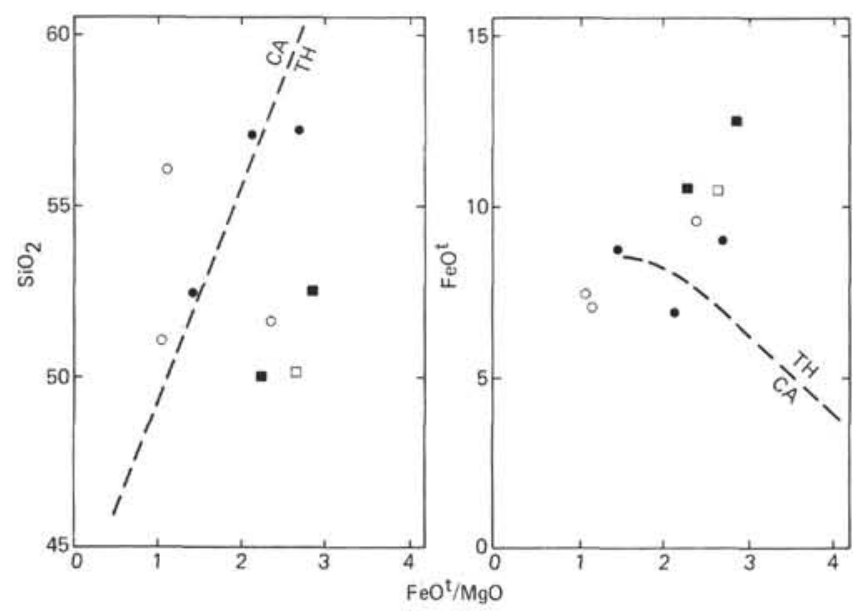

Figure 4. Silica and total iron as $\mathrm{FeO}^{t}$ plotted as a function of the ratio $\mathrm{FeO}^{\mathrm{t}} / \mathrm{MgO}$ wt. $\%$ for arc and remnant-arc samples (after Miyashiro, $1974 ; 1975) .(\mathrm{CA}=$ calc-alkalic field; $\mathrm{TH}=$ tholeitic field. Open square $=$ Hole 448; filled squares $=$ Hole 448A; open circles $=$ Hole 458 ; filled circles $=$ Hole 459B .)

$\mathrm{Mg} /\left(\mathrm{Mg}+\mathrm{Fe}^{+2}\right)(0.43$ and 0.48$)$. The youngest sample (459B-61-2, 42-46 cm) is a tholeiitic basalt with relatively low $\mathrm{TiO}_{2}$ and $\mathrm{K}_{2} \mathrm{O}$ and distinctly high $\mathrm{CaO}$. In Figure 4 these rocks are transitional between typical tholeiite and calc-alkaline compositions. Higher $\mathrm{Na}_{2} \mathrm{O}$ and $\mathrm{Na}_{2} \mathrm{O} / \mathrm{CaO}$ distinguish all three samples from arc samples farther west.

\section{Trace Elements}

Variations of seven trace elements in our sample suite are shown in Figure 3. In general, $\mathrm{Rb}, \mathrm{Sr}$, and $\mathrm{Ba}$ are markedly enriched and $\mathrm{Ni}$ and $\mathrm{Cr}$ depleted in arc and remnant-arc samples relative to basalts from the West Philippine Basin and Juan de Fuca suite. In contrast, V behaves somewhat erratically. Perhaps most surprising is the depletion of $\mathrm{Zr}$ in arc rocks compared to oceanfloor basalts.

With respect to $\mathrm{Ni}, \mathrm{Cr}$, and $\mathrm{V}$, basalts from the Juan de Fuca Ridge and West Philippine Basin fall in the normal range for MORB (Miyashiro and Shido, 1975). However, $\mathrm{Cr}$ abundances in JdF-P-269-6-4 and JdF-7123-3 are rather high (412 ppm and $706 \mathrm{ppm}$ respectively) and $\mathrm{Ni}$ concentrations unusually high $(365 \mathrm{ppm}$ and 357 ppm). Such $\mathrm{Ni}$ values are comparable to those calculated by Sato $(1977 ; \sim 400 \mathrm{ppm})$ and Mysen (1978, $\sim 300 \mathrm{ppm}$ ) for basaltic liquids in equilibrium with mantle peridotite, but they could also result in part from crystal accumulation in these olivine-phyric samples. The alkaline and alkaline-earth elements $\mathrm{K}, \mathrm{Rb}, \mathrm{Sr}$, and $\mathrm{Ba}$ are generally low in basalts from the ocean floor, with typical values for "normal" ridge segments given as $732 \mathrm{ppm} \mathrm{K}, 0.75 \mathrm{ppm} \mathrm{Rb}, 92 \mathrm{ppm} \mathrm{Sr}$, and $6 \mathrm{ppm} \mathrm{Ba}$ (White and Schilling, 1978). In comparison, basalts from the West Philippine Basin (Hole 447A) are normal to slightly low in $\mathrm{Sr}$, have quite normal $\mathrm{Ba}$ abundances, but appear slightly enriched in $\mathrm{Rb}$. Juan de Fuca basalts exhibit an anomalously large range of $\mathrm{Sr}(68-183 \mathrm{ppm})$ in spite of uniform ${ }^{87} \mathrm{Sr} / 86 \mathrm{Sr}$ ratios $(\sim 0.7025)$. $\mathrm{Zr}$ in these samples varies from $60 \mathrm{ppm}$ to $100 \mathrm{ppm}$, and V shows little variation from approximately $200 \mathrm{ppm}$.

Lavas from island arcs are typically more enriched in $\mathrm{Rb}, \mathrm{Sr}$, and $\mathrm{Ba}$ than are basalts from the ocean floor (Jakeš and White, 1972) and enable clear distinctions to be made between West Philippine Basin basalts and rocks of island-arc affinity farther east (Fig. 3). The relatively high $\mathrm{Ba}$ and $\mathrm{Sr}$ abundances in basalts of the Palau-Kyushu Ridge (Holes 448 and 448A) are particularly striking, whereas $\mathrm{Ba}$ and $\mathrm{Sr}$ in basalts and basaltic andesites (Holes 458 and 459B) in the active fore-arc region are enriched significantly over MORB but still somewhat low for typical arc tholeiites (Jakeš and Gill, 1970). At these sites, $\mathrm{K}$ and $\mathrm{Rb}$ are greater than typical MORB values by about an order of magnitude. The behavior of $\mathrm{Cr}, \mathrm{V}$, and $\mathrm{Ni}$ in calc-alkaline and tholeiite associations has been reviewed by Miyashiro and Shido (1975), who draw attention to the moderate increase of $\mathrm{V}$ in tholeiitic rocks with increasing differentiation, as opposed to its steady decline in the calc-alkalitic series. Although the mean concentration of $\mathrm{V}$ in our arc samples is fairly typical, the high values $(\sim 408 \mathrm{ppm})$ found in low $\mathrm{Mg} /\left(\mathrm{Mg}+\mathrm{Fe}^{+2}\right)$ basalts at Hole $448 \mathrm{~A}$ (Samples 448A-33-1, 100-108 cm and 448A-41-1, 2-7 $\mathrm{cm}$ ) apparently reflect the presence of abundant titanomagnetite microphenocrysts. The lowest $\mathrm{V}$ abundances $(142-172 \mathrm{ppm})$ are found in the magnesian andesites (Hole 458), which are also depleted in $\mathrm{Sr}, \mathrm{Zr}$, and $\mathrm{Y}$ but distinctly enriched in $\mathrm{Cr}$ (165-242 ppm) and $\mathrm{Ni}$ (64-97 $\mathrm{ppm}$ ) compared to other arc samples. $\mathrm{Y} / \mathrm{Zr}$ ratios are also notably low in the magnesian andesites.

$\mathrm{K} / \mathrm{Rb}$ in our sample suites varies from 229 to 1384 for basalts from the Juan de Fuca Ridge, 415 to 553 for Philippine Basin basalts, 643-760 for the Palau-Kyushu samples, and 213 to 792 for active arc rocks. The higher values are found in the remnant arc (Holes 448 and 448A).

The relatively "immobile" elements $\mathrm{Ti}, \mathrm{Y}, \mathrm{Zr}$, and $\mathrm{Nb}$ in volcanic rocks have been reviewed by Winchester and Floyd (1977). All the "immobile" trace-element data presented in Table 1 fall in the range of values that characterize subalkaline basalts. No further discriminations are evident.

\section{SR-ISOTOPIC COMPOSITION}

Observed $\mathrm{Sr}$-isotopic compositions are reported in Table 1. The samples are old enough (ages were taken from the preliminary site reports) and sufficiently rich in $\mathrm{Rb}$ to require a small correction from observed to initial ratios, also given in Table 1 . The isotopic pattern, shown graphically in Figure 1, is quite well defined and simple. At each site the initial ratios are remarkably uniform. Only at Holes 448 and $448 \mathrm{~A}$ is there a suggestion of variability beyond analytic error, with the low value for the stratigraphically lowest sample being confirmed by triplicate analyses.

The variation of ${ }^{87} \mathrm{Sr} / 86 \mathrm{Sr}$ ratios with tectonic setting is as expected-ratios of basin rocks are low, similar to those of MORB, and arc ratios are distinctly higher. Our average for the Juan de Fuca basalts $(0.70246 \pm$ 
0.00005 ) is indistinguishable from the average value of $0.7026 \pm 0.0002$ reported for similar samples by Hedge and Peterman (1970) and comparable to the precise data of Hart (1971) for fast-spreading ridges of the Pacific Ocean (0.70238). The Sr-isotope composition of the three samples from the Philippine Basin (Hole 447A) is 0.70261 and falls in the range $(0.7024-0.7031)$ expected for MORB (White and Bryan, 1977). Published data for the Mariana Trough (0.70263-0.70291 reported by Meijer, 1976, and Hart et al., 1972) are likewise in the normal range of MORB but slightly higher than Pacific Ridge or West Philippine Basin samples.

The most extensive isotopic and chemical work on rocks from the Mariana Arc is by Meijer (1976). His Srisotope ratios for frontal-arc and active volcanic-arc samples range from 0.70344 to 0.70400 , with an average of approximately 0.7037 . This is similar to western Pacific volcanic arcs in general (Gill and Compston, 1973). Stern (1979) reports somewhat lower values, 0.7032 to 0.7034 , for basalt and andesite of the island Agrigan in the Mariana Arc north of our transect. These are more like our results for the remnant-arc samples discussed later.

Our new ${ }^{87} \mathrm{Sr} /{ }^{86} \mathrm{Sr}$ data for Holes 458 and $459 \mathrm{~B}$ (for arc volcanics at the trench-slope break) average 0.70381 and 0.70364 , respectively. They are identical to those of the arc rocks exposed above sea level and quite distinct from the ratios for deep basins or ocean floor.

Holes 448 and 448A on the Palau-Kyushu Ridge yield slightly less radiogenic $\mathrm{Sr}$ than the average Mariana Arc sample as well as a barely distinct down-hole difference in isotopic composition. All three samples are distinctly more radiogenic than is the ocean floor. The deepest basalt analyzed, giving an initial ${ }^{87} \mathrm{Sr} / 86 \mathrm{Sr}$ ratio of 0.70333 , is less radiogenic than the two overlying basalts (0.70356), suggesting an increase in isotopic ratio with time at the site. A similar increase in ${ }^{87} \mathrm{Sr} / 86 \mathrm{Sr}$ with time has been observed and discussed by Donnelly et al. (1971) for igneous rocks of the Caribbean Arc.

The Sr-isotope data are only part of the isotopic complexion of these rocks. They cannot be used alone to distinguish between crustal contamination, anomalous mantle source, subducted altered basalt, or subducted sediments as the cause of higher ratios in arc rocks than in ocean floor. Any lengthy speculations await a synthesis of data from many sources. We hope the new data presented in this chapter will influence such speculation.

\section{ACKNOWLEDGMENTS}

R. B. Scott encouraged us to participate in this transect of the Mariana Arc. Krista Scott assisted in some of the analytic work and Roberta Crosby with manuscript preparation. Expenses were provided by an operating grant from the Natural Sciences and Engineering Research Council of Canada (A67-8841). D. J. Whitford and R. L. Chase reviewed the manuscript.

\section{REFERENCES}

Abbey, S., 1977. Studies in "standard samples" for use in the general analysis of silicate rocks and minerals. Part 5: 1977 edition of "usable" values. Can. Geol. Survey Paper 77-34, Ottawa, Canada (Publ. Dept. of Energy, Mines, and Resources), pp. 1-30.

Barr, S. M., 1972. Geology of the northern end of Juan de Fuca Ridge and adjacent continental slope [Ph.D. thesis]. University of British Columbia.
Bertrand, W. G., 1972. A geological reconnaissance of the Dellwood Seamount area, northeast Pacific Ocean, and its relationship to plate tectonics [M.Sc. thesis]. University of British Columbia.

Cameron, W. E., Nisbet, E. G., and Dietrich, V. J., 1979. Boninites, komatiites, and ophiolitic basalts. Nature, 280:550-553.

Cann, J. R., 1970. Rb, Sr, Y, Zr, and $\mathrm{Nb}$ in some ocean floor basaltic rocks. Earth Planet. Sci. Lett., 19:7-11.

de Laeter, J. R., and Hosie, D. J., 1977. Mass spectrometric isotope dilution analyses of barium in geochemical reference samples. Geostandards Newsletter, 1:143-145.

de Laeter, J. R., and Rosman, K. J. R., 1977. Trace element data on geostandards by mass spectrometric isotope dilution techniques. Geostandards Newsletter, 1:35-38.

Donnelly, T. W., Rogers, J. J. W., Pushkar, P., et al., 1971. The diverse origins of the igneous rocks of the eastern West Indies: an investigation of thorium, uranium, and potassium distribution and lead and strontium isotopic ratios. Geol. Soc. Am. Memoir 130:181-224.

Gill, J., and Compston, W., 1973. Strontium isotopes in island-arc volcanic rocks. In Coleman, P. J. (Ed.), The Western Pacific: Island Arcs, Marginal Seas, Geochemistry: Nedlands, W. Australia (University of W. Australia Press), pp. 483-496.

Hart, R. A., 1970. Chemical exchange between seawater and deepocean basalts. Earth Planet. Sci. Lett., 9:269-279.

Hart, S. R., 1969. K, Rb, Cs contents and K/Rb and K/Cs ratios of fresh and altered submarine basalts. Earth Planet. Sci. Lett., 6:295-303.

, 1971. K, Rb, Cs, $\mathrm{Sr}$, and $\mathrm{Ba}$ contents and $\mathrm{Sr}$ isotope ratios of ocean-floor basalts. Phil. Trans. Roy. Soc. London A, 268: 573-587.

Hart, S. R., Erlank, A. J., and Kable, E. J. D., 1974. Seafloor basalt alteration: some chemical and $\mathrm{Sr}$ isotope effects. Contrib. Mineral. Petrol., 44:219-230.

Hart, S. R., Glassley, W. E., and Karig, D. E., 1972. Basalts and seafloor spreading behind the Mariana Island Arc. Earth Planet. Sci. Lett., 15:12-18.

Hart, S. R., and Nalwak, A. J., 1970. K, Rb, Cs, and Sr relationships in submarine basalts from the Puerto Rico trench. Geochim. Cosmochim. Acta, 34:145-156.

Harvey, P. K., Taylor, D. M., Hendry, D., et al., 1973. An accurate fusion method for the analysis of rocks and chemically related materials by X-ray fluorescence spectrometry. X-Ray Spectrometry, 2:33-44.

Hawkins, J. W., Melchior, J., Bloomer, S., et al., 1979. Petrology of Mariana Trough and Mariana Arc basalts. EOS, 60:413.

Hedge, C. E., and Peterman, Z. E., 1970. The strontium isotopic composition of basalts from the Gordo and Juan de Fuca rises, northeastern Pacific Ocean. Contrib. Mineral. Petrol., 27:114120.

Hussong, D. M., 1978. Tectonics of the Mariana Islands fore-arc region; results of DSDP Leg 60. EOS, 59:1179.

Irvine, T. N., and Baragar, V. R. A., 1971. A guide to the chemical classification of the common volcanic rocks. Can. J. Earth Sci., 8:523-548.

Jakeš, P., and Gill, J., 1970. Rare-earth elements and the island-arc tholeiitic series. Earth Planet. Sci. Lett., 9:17-28.

Jakeš, P., and White, A. J. R., 1972. Major- and trace-element abundances in volcanic rocks of orogenic areas. Geol. Soc. Am. Bull., 83:29-40.

Karig, D. E., 1971. Structural history of the Mariana Island arc system. Geol. Soc. Am. Bull., 82:323-344.

1972. Remnant arcs. Geol. Soc. Am. Bull., 83:1057-1068. 1973. Comparison of island arc-marginal basin complexes in northwest and southwest Pacific. In Coleman, P. J. (Ed.), The Western Pacific: Island Arcs, Marginal Seas, Geochemistry: Nedlands, W. Australia (University of W. Australia Press), pp. 355-364.

Kay, R. W., 1978. Aleutian magnesian andesites: melts from subducted Pacific Ocean crust. J. Volcanol. Geotherm. Res., 4:117132.

Kikuchi, Y., 1889. On pyroxenic compounds in certain volcanic rocks from Bonin Island. J. Coll. Sci. Imp. Univ. Japan, 3:67-89.

Kuroda, N., Shiraki, K., and Urano, H., 1978. Boninite as a possible calc-alkalic primary magma. International Geodynamics Con- 
ference, Western Pacific and Magma Genesis, pp. 280-281. (Abstract)

Meijer, A., 1976. Pb- and Sr-isotopic data bearing on the origin of volcanic rocks from the Mariana Island-arc system. Geol. Soc. Am. Bull., 87:1358-1369.

, 1978. Petrology of volcanic rocks from the Mariana arctrench gap and gabbros from the Mariana inter-arc basin, IPOD, Leg 60. EOS, 59:1182.

Melson, W. G., Vallier, T. L., Wright, T. L., et al., 1976. Chemical diversity of abyssal volcanic glass erupted along Pacific, Atlantic, and Indian ocean seafloor spreading centers. Am. Geophys. Union Geophysical Monograph 19: Washington (Am. Geophys. Union), pp. 351-367.

Miyashiro, A., 1974. Volcanic rock series in island arcs and active continental margins. Am. J. Sci., 274:321-355. , 1975. Volcanic rock series and tectonic setting. Ann. Rev. Earth Planet. Sci., 3:251-269.

Miyashiro, A., and Shido, F., 1975. Tholeiitic and calc-alkalic series in relation to the behaviors of titanium, vanadium, chromium, and nickel. Am. J. Sci., 275:265-277.

Mysen, B. O., 1978. Experimental determination of nickel partition coefficients between liquid, paragasite, and garnet peridotite minerals and concentration limits of behavior according to Henry's law at high pressure and temperature. Am. J. Sci., 278:217-243.

Norrish, K., and Hutton, J. T., 1969. An accurate X-ray spectrographic method for the analysis of a wide range of geological samples. Geochim. Cosmochim. Acta, 33:431-453.

Pankhurst, R. J., and O'Nions, R. K., 1973. Determination of Rb/Sr and ${ }^{87} \mathrm{Sr} /{ }^{86} \mathrm{Sr}$ ratios of some standard rocks and evaluation of $\mathrm{X}$-ray fluorescence spectrometry in $\mathrm{Rb}-\mathrm{Sr}$ geochemistry. Chem. Geol., 12:127-136.

Pearce, J. A., and Cann, J. R., 1973. Tectonic setting of basic volcanic rocks determined using trace-element analyses. Earth Planet. Sci. Lett., 19:290-300.

Sato, H., 1977. Nickel content of basaltic magmas: identification of primary magmas and a measure of the degree of olivine fractionation. Lithos, 10:113-120.

Saunders, A. D., Marsh, N. G., and Tarney, J., 1978. Geochemistry of arc and inter-arc basalts from the East Mariana transect: IPOD Leg 60. EOS, 59:1182.

Stern, R. J., 1979. On the origins of andesite in the northern Mariana Island Arc: implications from Agrigan. Contrib. Mineral. Petrol., 68:207-219.

White, W. M., and Bryan, W. B., 1977. Sr-isotope, K, Rb, Cs, Sr, Ba, and rare-earth geochemistry of basalts from the FAMOUS area. Geol. Soc. Am. Bull., 88:571-576.

White, W. M., and Schilling, J.-G., 1978. The nature and origin of geochemical variation in Mid-Atlantic Ridge basalts from the Central North Atlantic. Geochim. Cosmochim. Acta, 42:1501-1516.

Winchester, J. A., and Floyd, P. A., 1977. Geochemical discrimination of different magma series and their differentiation products using immobile elements. Chem. Geol., 20:325-343.

\section{APPENDIX}

\section{Analytical Procedures}

Major- and trace-element analyses were obtained by X-ray fluorescence techniques (XRF) using a Phillips $1410 \mathrm{PW}$ spec- trometer. Major elements were determined on fused glass discs prepared with a lanthanum-bearing lithium tetraborate fusion mixture (CHEMPLEX Grade III). According to the procedures described by Harvey et al. (1973), we constructed least-squares calibration lines for each oxide and used values for international standards recommended by Abbey (1977). In the data reduction we employed the matrix correction factors determined by Norrish and Hutton (1969).

$\mathrm{Na}_{2} \mathrm{O}$ was analyzed using a pressed powder pellet and not corrected for matrix effects. $\mathrm{FeO}$ was determined by titration with potassium dichromate using barium diphenylamine sulphonate as indicator. Total $\mathrm{H}_{2} \mathrm{O}$ and $\mathrm{CO}_{2}$ were obtained gravimetrically by heating $1 \mathrm{~g}$ of sample in a furnace at approximately $1000^{\circ} \mathrm{C}$ under a constant flow of nitrogen. Magnesium perchlorate and Ascarite were used as chemical traps. $\mathrm{H}_{2} \mathrm{O}^{-}$was determined on a separate sample heated at $120^{\circ} \mathrm{C}$ for $8 \mathrm{~h} . \mathrm{H}_{2} \mathrm{O}^{+}$was calculated by subtracting $\mathrm{H}_{2} \mathrm{O}^{-}$from total $\mathrm{H}_{2} \mathrm{O}$.

During major-element oxide analysis, samples were excited using both $\mathrm{Cr}$ and $\mathrm{W}$ (Mn only) anodes operated at $50 \mathrm{kv}$ and $40 \mathrm{ma}$. Coarse collimation (except in the case of $\mathrm{Ca}$ and $\mathrm{Mn}$, where a fine collimator was used), flow-proportional counter, and TLAP and LiF (200) diffraction crystals were employed throughout. Backgrounds were measured for $\mathrm{P}, \mathrm{Mn}, \mathrm{Na}$, and $\mathrm{Mg}$.

Trace-element analyses were performed on pressed powder briquettes and corrected for instrument drift, background, spectral interference, and matrix effects. Mass absorption coefficients were calculated from major-element data for $\mathrm{Ba}, \mathrm{Cr}$, and $\mathrm{V}$ but determined experimentally for the other elements using the Mo $\mathrm{K}_{\alpha}$ Compton peak. We used LiF (200) crystal and evacuated x-ray path $(<0.3$ Torr $)$ throughout trace analysis. Other operating conditions were as follows:

$\mathrm{Nb}, \mathrm{Zr}, \mathrm{Y}$ : The $\mathrm{W}$ tube, operated at $50 \mathrm{kv}$ and $40 \mathrm{ma}$, fine collimator and scintillation plus flow-proportional counters.

$\mathrm{Ba}$ : The $\mathrm{Cr}$ tube, operated at $50 \mathrm{kv}$ and $40 \mathrm{ma}$, flowproportional counter, and a fine collimator.

$\mathrm{Ni}, \mathrm{Cr}, \mathrm{V}$ : The Mo tube, operated at $60 \mathrm{kv}$ and $40 \mathrm{ma}$, flowproportional and scintillation counters, coarse collimator, and an $\mathrm{Al}$ filter $\left(\mathrm{Cr}\right.$ and $\mathrm{Ni} \mathrm{K}_{\alpha}$ peaks only).

$\mathrm{Rb}, \mathrm{Sr}$ : The Mo tube, operated at $60 \mathrm{~kb}$ and $40 \mathrm{ma}$, scintillation counter, and fine collimator.

Values of standards used in the calibrations were taken from Abbey (1977), except in the case of $\mathrm{Ba}, \mathrm{Rb}$, and $\mathrm{Sr}$, where isotope dilution values were employed (de Laeter and Hosie, 1977; de Laeter and Rosman, 1977; Pankhurst and O'Nions, 1973).

During the period of analysis, reference standards were used to estimate the precision and accuracy of the analytical techniques. The results are presented in Table 1. Replicate analysis for $\mathrm{H}_{2} \mathrm{O}^{+}, \mathrm{H}_{2} \mathrm{O}^{-}$, and $\mathrm{CO}_{2}$ showed that precision is of the order of $5 \%$ to $10 \%$; for $\mathrm{FeO}$ precision is approximately $2 \%$.

$\mathrm{Sr}$-isotopic composition was measured on unspiked samples prepared using standard ion-exchange techniques. We washed all rock chips in warm $2.5 \mathrm{~N}$ quartz-distilled $\mathrm{HCl}$ for 30 minutes prior to crushing. The mass spectrometer $\left(60^{\circ}\right.$ sector, $30-\mathrm{cm}$ radius, solid source) is of U.S. National Bureau of Standards design and modified by $\mathrm{H}$. Faul. Data acquisition is digitized and automated using a NOVA computer. Experimental data have been normalized to a ${ }^{86} \mathrm{Sr} /{ }^{88} \mathrm{Sr}$ ratio of 0.1194 and adjusted so that the NBS standard $\mathrm{SrCO}_{3}$ (SRM987) gives a ${ }^{87} \mathrm{Sr} /{ }^{86} \mathrm{Sr}$ ratio of $0.71022 \pm 2$ and the Eimer and Amend $\mathrm{Sr}$ a ratio of $0.70800 \pm 2$. The precision of a single ${ }^{87} \mathrm{Sr} /{ }^{86} \mathrm{Sr}$ ratio is $0.0001(1 \sigma)$. 
Table 1. Instrumental precision and accuracy of majorand trace-element data.

\begin{tabular}{|c|c|c|c|}
\hline & \multicolumn{3}{|c|}{ BCR-1 (wt.\%) } \\
\hline & Analysis $\mathrm{A}^{\mathrm{a}}$ & Analysis $\mathrm{B}^{\mathrm{b}}$ & Precision $(2 \sigma)$ \\
\hline $\mathrm{SiO}_{2}$ & 54.71 & 54.66 & 0.42 \\
\hline $\mathrm{TiO}_{2}$ & 2.21 & 2.23 & 0.025 \\
\hline $\mathrm{Al}_{2} \mathrm{O}_{3}$ & 13.65 & 13.78 & 0.25 \\
\hline $\mathrm{Fe}_{2} \mathrm{O}_{3} \mathrm{t}$ & 13.51 & 13.54 & 0.24 \\
\hline $\mathrm{MnO}$ & 0.19 & 0.19 & 0.005 \\
\hline $\mathrm{MgO}$ & 3.48 & 3.48 & 0.13 \\
\hline $\mathrm{CaO}$ & 6.96 & 7.15 & 0.10 \\
\hline $\mathrm{Na}_{2} \mathrm{O}$ & 3.26 & 3.28 & 0.06 \\
\hline $\mathrm{K}_{2} \mathrm{O}$ & 1.68 & 1.72 & 0.06 \\
\hline \multirow[t]{3}{*}{$\mathrm{P}_{2} \mathrm{O}_{5}$} & 0.33 & 0.37 & 0.02 \\
\hline & \multicolumn{3}{|c|}{$\mathrm{W}-1$ (ppm) } \\
\hline & Analysis $\mathrm{A}^{\mathrm{a}}$ & Analysis $C^{c}$ & Precision $(2 \sigma)$ \\
\hline $\mathrm{Cr}$ & 120 & 110 & 11.3 \\
\hline $\mathrm{V}$ & 240 & 248 & 2.7 \\
\hline $\mathrm{Ni}$ & 78 & 79 & 2.7 \\
\hline $\mathrm{Zr}$ & 105 & 107 & 2.7 \\
\hline $\mathrm{Nb}$ & 9.5 & 9 & 2.0 \\
\hline \multirow[t]{3}{*}{ Y } & 25 & 26 & 2.3 \\
\hline & \multicolumn{3}{|c|}{$\mathrm{GH}$ (ppm) } \\
\hline & Analysis $\mathrm{D}^{\mathrm{d}}$ & Analysis $C^{c}$ & Precision $(2 \sigma)$ \\
\hline $\mathrm{Ba}$ & 17.2 & 15.8 & 8 \\
\hline
\end{tabular}

Note: $\mathrm{Rb} / \mathrm{Sr}$ ratios have a precision of $2 \%$ (or 0.003 ) $(1 \sigma)$ and $\mathrm{Rb}$ and $\mathrm{Sr}$ concentrations a precision of $5 \%$ (or $0.3 \mathrm{ppm}$ ) $(1 \sigma) . \mathrm{Fe}_{2} \mathrm{O}_{3}{ }^{\mathrm{t}}=$ total iron expressed as $\mathrm{Fe}_{2} \mathrm{O}_{3}$.

a Values recommended by Abbey (1977)-major-element oxides on a volatile-free basis.

$\mathrm{b}$ Average of 12 determinations on a single fused disc.

c Average of 10 determinations on pressed powder pellets.

d Determined by isotope dilution (de Laeter and Hosie, 1977; de Laeter and Rosman, 1977). 